\title{
Association of menstrual cycle related symptoms with mood changes
}

\author{
Tamas Telek $^{1 *}$, Xenia Gonda ${ }^{1,2}$, Gabor Csukly ${ }^{3}$, Kostas Fountoulakis ${ }^{4}$, Gyorgy Bagdy $^{1}$ \\ From $1^{\text {st }}$ International Congress on Neurobiology and Clinical Psychopharmacology \\ and European Psychiatric Association Conference on Treatment Guidance \\ Thessaloniki, Greece. 19-22 November 2009
}

\section{Background}

Nearly $80 \%$ of women experience some worsening of physiological and psychological symptoms a few days before the onset of menstruation, and these symptoms have an influence on well-being, and behaviour. Due to the premenstrual-period related symptoms relationship, family, and work-related conflicts may occur. Even economical loss has to be taken into consideration due to decrease in ability to work, and staying out of work. The aim of our study was to investigate the association between mood changes troughout the menstrual cycle phases of healthy women.

\section{Materials and methods}

88 healthy women not meeting criteria for any DSM-IV premenstrual phase-associated disorders completed the STAI State Anxiety Scale (STAI-S), SCL-51 and the ZSDS during first cycle on three predefined days (early follicular, late follicular and late luteal phase). Data were analysed using Generalized Linear Model Analysis (GENMOD).

\section{Results}

A significant effect of phase of the cycle was observable in case of the state anxiety scale $(\mathrm{F}=6.27, \mathrm{p}=0.0022)$, the SCL-51 total score $(\mathrm{F}=5.31, \mathrm{p}=0.0055)$, the somatization subscale of the SCL51 ( $\mathrm{F}=4.16, \mathrm{p}=0.0167)$, the depression subscale of the SCL51 $(F=4.58$, $\mathrm{p}=0.0111)$, the obsessive-compulsive subscale of the SCL51 $(\mathrm{F}=3.63, \mathrm{p}=0.0278)$ and the interpersonal sensitivity scale of the SCL51 ( $F=5.71, p=0.0038)$. Significant effect of phase also emerged on the ZSDS $(\mathrm{F}=3.14, \mathrm{p}=0.0452)$.

${ }^{1}$ Department of Pharmacology and Pharmacotherapy, Semmelweis University, Budapest, Hungary

\section{Conclusions}

In case of healthy women there is a significant fluctuation during the menstrual cycle in anxiety, somatisation, depression, obsessive compulsive symptoms and interpersonal sensitivity, so in the majority of women psychological well-being is significantly associated with the phase of the cycle. In case of psychological and psychiatric investigations, cycle phase thus should be taken into consideration since it may influence measurements even in case of healthy women.

\section{Acknowledgements \\ These studies were supported by the Sixth Framework Programme of the EU, LSHM-CT-2004-503474 and the PhD Fellowship Program of the} Semmelweis University, Ministry of Culture and Education, Hungary.

\section{Author details}

${ }^{1}$ Department of Pharmacology and Pharmacotherapy, Semmelweis University, Budapest, Hungary. ${ }^{2}$ Department of Psychiatry Kutvolgyi Klinikai Tömb, Semmelweis University, Budapest, Hungary. ${ }^{3}$ Department of Psychiatry and Psychotherapy, Semmelweis University, Budapest, Hungary. ${ }^{4} 3 r d$ Department of Psychiatry, Section of Neurosciences, Faculty of Medicine, Aristotle University of Thessaloniki, Greece.

Published: 22 April 2010

References

1. Gonda X, Telek T, Juhasz G, Lazáry J, Vargha A, Bagdy Gy: Patterns of mood changes throughout the reproductive cycle in healthy women without premenstrual dysphoric disorders. Progress in NeuroPsychopharmacology \& Biological Psychiatry 2008.

2. Gonda X, Lazáry J, Telek T, Pap D, Kátai Z, Bagdy Gy: Mood parameters and severe physical symptoms of the female reproductive cycle. Neuropsychopharmacologia Hungarica X/2 2008, 83-88.

3. Telek T, Gonda X, Lazáry J, Benkő A, Bagdy Gy: A premenstruális szindróma pszichikai és fizikai változásainak vizsgálata. 5. Vajdasági Magyar Tudományos Diákköri Konferencia Újvidék, Konferenciakiadvány 2006, 59-60.

doi:10.1186/1744-859X-9-S1-S202

Cite this article as: Telek et al.: Association of menstrual cycle related symptoms with mood changes. Annals of General Psychiatry 2010 9(Suppl 1):S202. 